\title{
Occupational risk factors for nasopharyngeal cancer in Sweden
}

\author{
H S R Malker, J K McLaughlin, J A Weiner, Debra T Silverman, W J Blot, J L E Ericsson, \\ J F Fraumeni, Jr
}

Few occupational risk factors have been identified for nasopharyngeal cancer, ${ }^{1}$ although reported associations with poor ventilation, ${ }^{2}$ smoke, dust, and fumes, ${ }^{3}$ and exposure to formaldehyde ${ }^{4-6}$ have suggested that inhalation of carcinogens may play an aetiological part. To provide further leads to occupational risks for this uncommon tumour, we examined on a national basis the association between employment and nasopharyngeal cancer using the Swedish Cancer-Environment Registry (CER).

\section{Methods}

The CER and statistical methods used to calculate standardised incidence ratios (SIRs) have been described. ${ }^{7}$ The SIR is the ratio of observed to expected cases of nasopharyngeal cancer for the period 196179 among men in occupational groups defined by employment in 1960. Only statistically significant $(p<0.05)$ increases of SIRs are reported for specific (three digit) occupations and industries.

\section{Results}

There were 471 incident cases of nasopharyngeal cancer among employed Swedish men during the period 1961-79. Microscopic confirmation was obtained for $99.6 \%$ of the cases: $48 \%$ were squamous cell carcinomas, 37\% unspecified carcinomas, 5\% transitional cell carcinomas, and 3\% adenocarcinomas. The remaining $7 \%$ were distributed across several histological types or were of unspecified type.

The table presents occupations and industries with significantly raised SIRs. The highest risks were observed for glassmakers (SIR $=6.2$ ) and bookbinders ( $\operatorname{SIR}=6 \cdot 1)$, based on three cases each. $A$

National Board of Occupational Safety and Health, Solna, Sweden

H S R Malker, J A Weiner

Epidemiology and Biostatistics Program, Division of Cancer Etiology, National Cancer Institute, Bethesda, Maryland 20892, USA

J K McLaughlin, D T Silverman, W J Blot, J F Fraumeni, Jr

National Board of Health and Welfare, Stockholm, Sweden

J L E Ericsson significantly increased risk was observed for shoemakers (SIR $=3.8$ ); the same workers were at increased risk by industry category (SIR $=4 \cdot 0)$.

Men employed in fibreboard plants had a significantly increased risk (SIR = 3.9), based on four cases. As a result other occupations (occ) and industries (ind) with potential for exposure to formaldehyde in Sweden were examined. ${ }^{89}$ No significantly high risks were seen among textile workers (SIR $=0.4$; one case; occ 701), furniture makers $($ SIR $=0.8$; three cases; ind 250$)$, or chemical workers $(\operatorname{SIR}=0.6$, one case; occ 831). No cases of nasopharyngeal cancer were observed in other groups with potential for exposure to formaldehyde in Sweden such as physicians (occ 031), foundry workers (occ 736), biologists (occ 022), tanners and skin processors (occ 853), and workers employed in veneer and plywood plants (ind 242) and in sugar processing plants (ind 206).

\section{Discussion}

Several aetiological leads were uncovered by examining the Swedish CER for occupationally related risks of nasopharyngeal cancer. Most noteworthy is a fourfold increased risk for men employed in plants manufacturing fibreboard, a process using formaldehyde based urea resins, ${ }^{8-10}$ plus exposure to wood and other dusts. ${ }^{11}$ Furthermore, an excess risk was seen among bookbinders, who are also potentially exposed to formaldehyde and glues, inks, and solvents. ${ }^{12}$ These findings are interesting in view of reports

Statistically significant $(p<0.05)$ SIRs for nasopharyngeal cancer for specific (three digit) occupations and industries

\begin{tabular}{llll}
\hline Code & Title & No of cases & SIR \\
\hline & & Occupation & \\
811 & Glassmaker & 3 & \\
806 & Bookbinders & 3 & $6 \cdot 2$ \\
721 & Shoemaker & 5 & $6 \cdot 1$ \\
& & & $3 \cdot 8$ \\
232 & Shoe repair & 5 & \\
263 & Fibreboard plant & 4 & $4 \cdot 0$ \\
\hline
\end{tabular}

^Adjusted for age and region. 
linking nasopharyngeal cancer and occupational contact with formaldehyde, ${ }^{4-6}$ particularly when combined with exposure to particulate matter. ${ }^{4}$ Also, a raised risk of nasopharnygeal cancer has been reported among mobile home residents exposed to formaldehyde emanating from construction and insulation materials. ${ }^{13}$

Examination of other job categories with exposure to formaldehyde in Sweden showed no significantly raised SIRs. ${ }^{89}$ This may reflect the limitation of the job coding scheme used in the CER-for instance, lack of detailed occupational categories such as formaldehyde resin makers, taxidermists, pathologists, and anatomists-and the small number of workers in groups heavily exposed to formaldehyde.

The excess risk of nasopharyngeal cancer among shoemakers in the shoe repair industry is interesting in the light of exposures to solvents, adhesives, and cleaners which contain potential carcinogens. ${ }^{112}$ Adenocarcinomas of the nasal cavity and sinuses have been linked to employment in boot and shoe manufacturing and repair, ${ }^{11}$ although our analysis of nasal cancer in Sweden found no such association. ${ }^{14}$ Another new finding includes the significantly increased risk of nasopharyngeal cancer for glassmakers, who have potential exposures to silica, alkaline dusts, inorganic arsenic, chromium, and lead. ${ }^{15}$

We have described the shortcomings of the CER elsewhere. ${ }^{7}$ Because of the limited nature of the employment data (derived from census interviews), causal inferences are difficult to draw. A special concern is the problem of multiple comparisons, which enhances the likelihood of detecting findings based on chance. The high risk occupations identified in our study, however, were limited to industrial groups and did not extend to white collar occupations as one might expect if only chance were operating.
Requests for reprints to: Dr H S R Malker, National Board of Occupational Safety and Health, Solna, Sweden.

1 Shanmugaratnam K. Nasopharynx. In: Scottenfeld D, Fraumeni JF, Jr, eds. Cancer epidemiology and prevention. Philadelphia: WB Saunders, 536-53.

2 Lin TM, Chen KP, Lin CC, et al. Retrospective study on nasopharyngeal carcinoma. J Natl Cancer Inst 1973;51: 1403-8.

3 Henderson BE, Louie E, Jing JS, Buell P, Gardner MB. Risk factors associated with nasopharyngeal carcinoma. $N$ Engl $J$ Med 1976;295:1101-6.

4 Blair A, Stewart PA, Hoover RN, et al Cancer of the nasopharynx and oropharynx and formaldehyde exposure. $J$ Natl Cancer Inst 1987;78:191.

5 Roush GC, Walrath J, Stayner LT, Kaplan SA, Flannery JT, Blair A. Nasopharynx cancer, sinonasal cancer, and occupations related to formaldehyde: a case-control study. $J$ Natl Cancer Inst 1987;79:1221-4.

6 Vaughn TL, Strader C, Davis S, Daling JR. Formaldehyde and cancer of the pharynx, sinus, and nasal cavity: I. Occupational exposure. Int J Cancer 1986;38:677-83.

7 Malker HSR, McLaughlin JK, Malker BK, et al. Biliary tract cancer and occupation in Sweden. $\mathrm{Br} J$ Ind Med 1986;43: 257-62.

8 Malker H, Weiner J. The cancer-environment registry, 19611973. Examples of the use of register epidemiology in studies of the work environment. Arbete och Halsa 1984;9:80-3.

9 Rosen G, Bergstrom B, Ekholm U. Occupational exposure to formaldehyde in Sweden. Arbete och Halsa 1984;50:1-25.

10 International Agency for Research on Cancer. Monographs on the evaluation on the carcinogenic risk to humans. Vol 29. Some industrial chemicals and dyestuff. Lyon: IARC, 1982:345-89.

11 International Agency for Research on Cancer. Monographs on the evaluation on the carcinogenic risk to humans. Vol 25. Wood, leather and some associated industries. Lyon: IARC, 1981: 99-138.

12 Key MM, Henchel AF, Butler J, Ligo RN, Tabershaw IR. Occupational diseases: a guide to their recognition. Cincinnati: National Institute for Safety and Health. (DHEW publ No 77-181.)

13 Vaughn TL, Strader C, Davis S, Daling JR. Formaldehyde and cancers of the pharynx, sinus and nasal cavity: II. Residential exposure. Int J Cancer 1986;38:685-8.

14 Malker HSR, McLaughlin JK, Blot WJ, et al. Nasal cancer and occupation in Sweden. Am J Ind Med 1986;9:477-85.

15 International Labor Office. Encyclopedia of occupational health and safety. Vol 1. 3rd ed. Geneva: ILO, 1983:966-70.

Accepted 18 May 1989 